Available online at www.sciencedirect.com

\title{
Lightning, fire and longleaf pine: Using natural disturbance to guide management
}

\author{
Kenneth W. Outcalt* \\ Southern Research Station, USDA Forest Service, 320 Green Street, Athens, GA 30602, United States
}

Received 21 November 2007; received in revised form 11 February 2008; accepted 12 February 2008

\begin{abstract}
The importance of lightning as an ignition source for the fire adapted longleaf pine (Pinus palustris) ecosystem is widely recognized. Lightning also impacts this system on a smaller scale by causing individual tree mortality. The objective of this study was to determine mortality due to lightning and other agents in longleaf stands on the Ocala National Forest in central Florida and to quantify lightning ignited fire. Mortality from lightning was also tracked in longleaf stands on the Savannah River Site in South Carolina. Lightning killed more trees than any other agent with a mean mortality of nearly 1 tree/3 ha/yr in Florida and 1 tree/8 ha/yr in South Carolina. The probability of a tree being struck by lightning increased as a function of tree height at both sites, i.e. lightning preferentially removed the largest trees from the stand. In addition lightning strikes were clumped within stands, sometimes killed multiple trees with a single strike, and often hit trees on the edge of existing gaps. The combination of these processes means gaps suitable for regeneration within longleaf stands are created quite rapidly. This information provides guidelines for the development of selection harvest systems based on this natural disturbance. Although lightning activity was greatest during the summer months in Florida and most fires occurred in June, the probability of a strike causing a fire was highest in February to May.

Published by Elsevier B.V.
\end{abstract}

Keywords: Pinus palustris; Disturbance; Wildfire; Mortality; Selection Silviculture

\section{Introduction}

Longleaf pine was once a very common tree in the Southeast dominating 24.3 million ha, stretching from southeastern Virginia, south to central Florida, and west into eastern Texas (Stout and Marion, 1993). As a result of cumulative impacts wrought by timber harvest followed by conversion to other tree species and land clearing for agriculture and urban uses, longleaf pine forest types have declined significantly and now occupy less than $5 \%$ of their original area (Outcalt and Sheffield, 1996). Longleaf communities have a diversity of ground cover plants with as many as 140 species of vascular plants in a $1000 \mathrm{~m}^{2}$ area (Peet and Allard, 1993). Many of these species are local endemics or exist largely in the shrinking longleaf pine dominated habitats (Hardin and White, 1989; Walker, 1993).

It has been theorized that using techniques, which mimic natural disturbances, should maintain biodiversity and ecosys-

\footnotetext{
* Tel.: +1 706559 4309; fax: +1 7065594317

E-mail address: koutcalt@fs.fed.us.
}

tem integrity (Franklin, 1992). This is based on the premise that species within the community are adapted to natural disturbance and thus are resilient or resistant to these perturbations. This nature-based approach has been advocated for management and restoration of European forest types (Fries et al., 1997). Palik et al. (2002) also suggested modeling silviculture based on natural disturbance as a way to sustain the biodiversity of longleaf pine ecosystems of the southern United States.

A critical first step in development of nature based silvicultural systems is an understanding of natural disturbance processes for the forest type of interest. For longleaf pine these disturbances range from wide scale impacts like fire to individual tree mortality from insects or pathogens. Frequent low intensity surface fires were the most widespread and major disturbance factor shaping longleaf pine ecosystems. Prior to landscape fragmentation, these natural fires occurred every 2-8 years across the species' range (Christensen, 1981; Abrahamson and Hartnett, 1990; Ware et al., 1993). Lightning and Native Americans provided the ignition sources for these fires, which shaped the vegetation of the region (Komarek, 1964; Robbins and Myers, 1992). 
Another significant disturbance agent in longleaf ecosystems was wind. A good portion of the longleaf range lies within $160 \mathrm{~km}$ of the coast. Thus, stands had a high probability of being impacted by a significant hurricane at least once every 100 years (Hooper and McAdie, 1995). Tornadoes were also prevalent within the longleaf range. For the period of 1880 1982 there were 969 major tornadoes across the south or 9.5 per year (Martin and Boyce, 1993). Although covering much smaller areas, tornadoes can cause significant disturbance on a local stand scale.

Lightning also has long been recognized as an important disturbance in southern pine ecosystems where in addition to being an ignition source it also impacted this system on a smaller scale by causing individual tree mortality (Komarek, 1968; Taylor, 1974). Reynolds (1940) reported $70 \%$ of pine mortality on the Crossett Experimental Forest in Arkansas over a 2-year period was due to lightning. In 182 ha of mature pine and pine hardwood stands near Georgetown, South Carolina 80 trees were killed by lightning over a 3year period (0.44 trees/ha/yr) (Harlow and Guynn, 1983). Baker (1974) recorded one lightning struck tree per 18 ha annually $(0.055$ trees/ha/yr) in pine stands at Tall Timbers Research Station near Tallahassee, Florida. In southeast Georgia pine stands, lightning mortality in 1968 was much higher at 27 trees on 16 ha (1.68 trees/ha/yr) (Paul and Waters, 1978). Although lightning caused tree mortality data does exists, it is apparent that it is variable from place to place and from year to year. In addition, existing data does not provide information on seasonal variation within a given year. The major objective of this study was to quantify tree mortality from lightning and other agents in longleaf pine stands and to determine seasonal and annual variation in lightning caused mortality. A secondary objective was to estimate seasonal lightning ignition probabilities for central Florida.

\section{Methods}

\subsection{Study sites}

The primary portion of this study was located on the Ocala National Forest in central Florida. The climate of this region is humid subtropical with abundant rainfall of $1300 \mathrm{~mm} / \mathrm{yr}$ (Chen and Gerber, 1990). Much of this rainfall comes during the spring and summer months from thunderstorms. Central Florida averages 90 thunderstorm days per year, more than anywhere else in the United States. It has a correspondingly high number of lightning strikes with 10-12 cloud to ground discharges $/ \mathrm{km}^{2} / \mathrm{yr}$ (Hodanish et al., 1997). The soils are mostly entisols derived from sandy marine and Aeolian deposits of past glacial and interglacial episodes (Laessle, 1958). The dominant natural vegetation of the area was composed of two contrasting types, scrub and high pine (Myers, 1990). Historically scrub was dominated by a twisted overstory of Ocala sand pine (Pinus clausa var. clausa) with an understory of evergreen shrubs. High pine areas were dominated by longleaf pine growing in an open park-like stands over a grass- dominated understory with occasional individual or clumps of oaks (Quercus spp.).

A secondary study area was located on the U.S. Department of Energy Savannah River Site in west central South Carolina. This area has a long growing season of 246 days, a summer mean temperature of $26.5^{\circ} \mathrm{C}$, and annual precipitation of $1200 \mathrm{~mm}$ with about half falling between April and September (USDA, 1941). Thunderstorms are less prevalent than in Florida, but still common, with associated lightning strikes occurring at a density of 3-5 cloud to ground strikes $/ \mathrm{km}^{2} / \mathrm{yr}$ (Orville, 1994). The Savannah River site lies in the fall line transition zone from upper coastal plain to piedmont. It is composed of Pliocene and Pleistocene coastal terraces and sandhills. Soils derived from predominately sandy parent materials are mostly entisols, which occupy $60-80 \%$ of the area (Brooks and Crass, 1991). Longleaf pine forests dominated these sandy sites prior to clearing for agriculture beginning in 1740.

In April 1992, four longleaf pine stands were randomly selected on the Ocala National Forest. The stands on the Lake George district were 27.7 and 25.9 ha while those on the Seminole were 18.9 and 7.6 ha. The Lake George stands were on Riverside Island, which is a large area of longleaf pine surrounded by stands of Ocala sand pine. These stands of longleaf were called islands by early settlers because they were oval, there was a sharp boundary between them and the surrounding sand pine scrub, and they differed markedly in appearance. Stands on the Seminole district were in Paisley Woods, which is a much more contiguous concentration of longleaf dominated community with some fingers and inclusions of Ocala sand pine. All stands were second growth longleaf pine that originated following logging in the early 1900 s, from trees too small to harvest or subsequent natural regeneration. Some selective harvesting via thinning had occurred between 1940 and the late 1970s when cutting was discontinued to protect red-cockaded woodpecker habitat. Stands had been prescribed burned every 3-4 years for at least two decades with a majority of burning during the growing season for the last 10 years.

\subsection{Data collection and analyses}

After selection, the perimeter of each stand was mapped using a GPS unit. Data from the GPS files were used to calculate total stand area. During an initial survey of each stand, all existing dead standing trees were marked with red paint. Within each stand 0.125 ha circular plots, one for each 5 ha of stand area, were systematically located beginning from a randomly selected starting point. Species, diameter breast height (dbh), and height were recorded for all trees greater than $5 \mathrm{~cm}$ dbh on these plots. An additional $50 \mathrm{~m} \times 100 \mathrm{~m}$ plot was randomly located in each stand. Within these plots, the location of each tree greater than $5 \mathrm{~cm}$ dbh was mapped and dbh and height data were gathered. Data from circular and rectangular plots were combined to determine stand characteristics including mean dbh and height, diameter and height class distribution and basal area. 
To track tree mortality from lightning and other causes, each stand was surveyed monthly until 1997 when surveys were reduced to semi-annual. Height, dbh, and age were determined for each dead or dying tree. A GPS reading was also taken and for those hit by lightning, its relative location within the stand was recorded. Relative stand location of struck trees was classed as on the edge of a current gap, creating a new gap, or within the forest matrix. A gap was defined as any opening with a diameter of at least $24 \mathrm{~m}$ measured between the bases of living non-lightning affected trees. This distance was chosen to represent a true gap because this is the threshold where probability of successful longleaf regeneration markedly increases in sandhills habitat of this region (Brockway and Outcalt, 1998).

Similar procedures were followed on the Savannah River Site where in 1993 seven longleaf pine stands were randomly selected from all longleaf stands over 30 years old. All were stands established by direct seeding on old field sites in the 1950s. Prescribed burning had been non-existent or sporadic in most stands until the last decade. Boundaries of selected stands were mapped with a laser transit and this information used to calculate area. Stands ranged is size from 14.2 ha up to 63 ha with a mean of 36.4 ha. Initial survey data collection followed the same procedures as used on the Ocala except circular plots were 0.1 ha and at a density of one plot/3 ha of stand area. Each stand was surveyed semi-annually from 1993 through 1996 to track lightning caused mortality, but relative stand location of struck trees was not recorded.

Tree size and mortality rates for the different mortality agents were compared using analyses of variance with stands treated as replications. Data from Florida and South Carolina were analyzed separately with significant differences between means based on Fisher's least significant difference measure at 0.05 level, when the analyses of variance yielded a significant $F$ statistic. Standard linear regression (Hintze, 1995) was used to test for a relationship between tree size and the $\log$ of probability of being struck by lightning.

The mapped locations of trees in $50 \mathrm{~m} \times 100 \mathrm{~m}$ sample plots on the Ocala National Forest were used to determine tree spatial patterns. A spatial pattern analysis was performed using the $K(t)$ function (Ripley, 1981). This function uses tree-to-tree distances compared to Monte Carlo simulations of expected distributions to assess the significant deviations from the null hypothesis of a random distribution. Simulations were run to generate $99 \%$ confidence intervals using SPPA 2.0 software (Haase, 2002), which also produces a plot of the $L(t)$ against distance and a suitable test statistic of significance (Haase, 2001). This method of spatial pattern analyses was also used on lightning struck trees on the Ocala National Forest after locations were transformed into $x$ and $y$ coordinates.

\section{Results}

\subsection{Stand characteristics and tree mortality}

Stands on the Ocala National Forest were dominated by longleaf pine with a few scattered Ocala sand pine and occasional midstory turkey (Quercus laevis) and blue jack ( $Q$. incana) oaks. Longleaf pine had greater mean size in the two stands on Riverside Island of the Lake George district with dbh $27.3 \mathrm{~cm}$ and height $21.2 \mathrm{~m}$ versus $23.8 \mathrm{~cm}$ and $18.3 \mathrm{~m}$ for stands on the Seminole district. Stands were quite open with a mean stocking of 209 trees/ha and basal area at $9.9 \mathrm{~m}^{2} / \mathrm{ha}$, which is typical of sandhills longleaf stands of this region. The longleaf stands on the Savannah River Site were 40 years old but the trees were nearly as large as the older trees in natural stands on the Ocala with mean dbh of $23.9 \mathrm{~cm}$ and height of $22 \mathrm{~m}$. These stands were denser with 366 longleaf trees/ha and a mean basal area twice that of Ocala stands at $19.5 \mathrm{~m}^{2} / \mathrm{ha}$.

In Florida, trees that died were larger in both diameter and height than the overall stand mean $25.6 \mathrm{~cm}$ dbh and $19.8 \mathrm{~m}$ tall, regardless of mortality cause (Table 1). Trees killed over the 4year period in South Carolina also had a greater diameter than the stand mean. At both locations trees killed by insects were smaller in diameter than those killed by lightning. The lightning killed trees were also tallest, averaging nearly $3 \mathrm{~m}$ above mean stand height of $22 \mathrm{~m}$ in South Carolina and $4 \mathrm{~m}$ taller in Florida. The mean annual mortality rate was 0.443 longleaf pines/ha/yr over the 10 year study period on the Ocala and 0.206 for the 4 years we tracked it on the Savanna River Site. In Florida, prescribed burning killed the fewest trees, with the rate from unknown causes essentially the same. Insect and wind caused

Table 1

Size, age and mortality rate of longleaf pine by mortality agent over a 10-year period in selected stands on the Ocala National Forest, Florida and a 4-year period at Savannah River Site, South Carolina

\begin{tabular}{llllll}
\hline Mortality cause & Mean diameter $(\mathrm{cm})$ & Mean height $(\mathrm{m})$ & Mean age $(\mathrm{yr})$ & Mortality rate $($ trees/ha/yr) & Basal area loss $\left(\mathrm{m}^{2} / \mathrm{ha} / \mathrm{yr}\right)$ \\
\hline Ocala National Forest & & & & & \\
Unknown & $33.3 \mathrm{ab}$ & $20.5 \mathrm{a}$ & $57 \mathrm{a}$ & $0.021 \mathrm{a}$ & $0.002 \mathrm{a}$ \\
Insects & $29.4 \mathrm{a}$ & $21.2 \mathrm{a}$ & $57 \mathrm{a}$ & $0.036 \mathrm{a}$ & $0.003 \mathrm{a}$ \\
Fire & $33.9 \mathrm{ab}$ & $23.0 \mathrm{~b}$ & $60 \mathrm{a}$ & $0.017 \mathrm{a}$ & $0.002 \mathrm{a}$ \\
Wind & $35.2 \mathrm{~b}$ & $20.7 \mathrm{a}$ & $\mathrm{ND}^{\mathrm{a}}$ & $0.044 \mathrm{a}$ & $0.004 \mathrm{a}$ \\
Lightning & $34.2 \mathrm{~b}$ & $23.3 \mathrm{~b}$ & $65 \mathrm{a}$ & $0.294 \mathrm{~b}$ & $0.028 \mathrm{~b}$ \\
Savannah River Site & & & & & $0.001 \mathrm{a}$ \\
$\quad$ Unknown & $26.7 \mathrm{a}$ & $20.3 \mathrm{a}$ & ND & $0.021 \mathrm{a}$ & $0.003 \mathrm{a}$ \\
Insects & $27.3 \mathrm{a}$ & $21.4 \mathrm{a}$ & ND & $0.054 \mathrm{a}$ & $0.013 \mathrm{~b}$ \\
Lightning & $34.2 \mathrm{~b}$ & $24.8 \mathrm{~b}$ & ND & $0.132 \mathrm{~b}$ & \\
\hline
\end{tabular}

Means within a column, at each site, not followed by the same letters (a and b) are significantly different at 0.05 level.

${ }^{a} \mathrm{ND}$ is no data was collected. 
mortality rates were not significantly different than those caused by burning. Lightning was the primary mortality agent for longleaf pines in stands in both states. It caused the death of 236 out of 354 trees $(67 \%)$ that died on the 80 ha study area of the Ocala National Forest during 10 years and $62 \%$ of trees killed in the 255 ha of longleaf stands studied in South Carolina.

\subsection{Lightning activity}

Sometimes lightning spreads or splinters into multiple leaders near the ground. Just over $20 \%$ of strikes in the Florida portion of this study were of this multiple leader type that hit mostly two but sometimes as many as four trees simultaneously. After adjusting for these multiple tree hits, lightning density in study stands on the Ocala was 23 strikes $/ \mathrm{km}^{2} / \mathrm{yr}$.

Florida stands sampled contained 16,692 live longleaf pine greater than $5 \mathrm{~cm}$ dbh and 104 dead standing snags. During the study, 236 trees were hit by lightning yielding a mean annual strike probability of $0.14 \%$, while two snags were hit by lightning or a probability of $0.19 \%$. The smallest tree hit by lightning during the study was $11.5 \mathrm{~m}$ tall and $13.5 \mathrm{~cm} \mathrm{dbh}$ while the largest had a height of $33.5 \mathrm{~m}$ and a dbh of $54 \mathrm{~cm}$. There was a significant relationship between tree height and probability of a lightning strike. Probability increased on a semi-log scale with tree height from an annual probability of $0.01 \%$ for a tree $12 \mathrm{~m}$ tall to an annual rate of $1.5 \%$ for trees $30 \mathrm{~m}$ or taller. After transformation the regression was: $\log$ (probability of lightning strike $)=-3.333+0.0792 \times$ tree height with an $R^{2}$ of 0.87 (Fig. 1). Because trees that died were larger than average, the losses based on basal area were double that based on stem numbers with $0.28 \%$ of basal area killed by lightning annually. These same trends were noted in South Carolina where lightning strike probability increased for taller trees with a semi-log relationship.

For the 5 years that monthly lightning mortality was tracked in Florida stands, there were no trees hit in January, February or December (Fig. 2). Lightning struck the most trees in longleaf

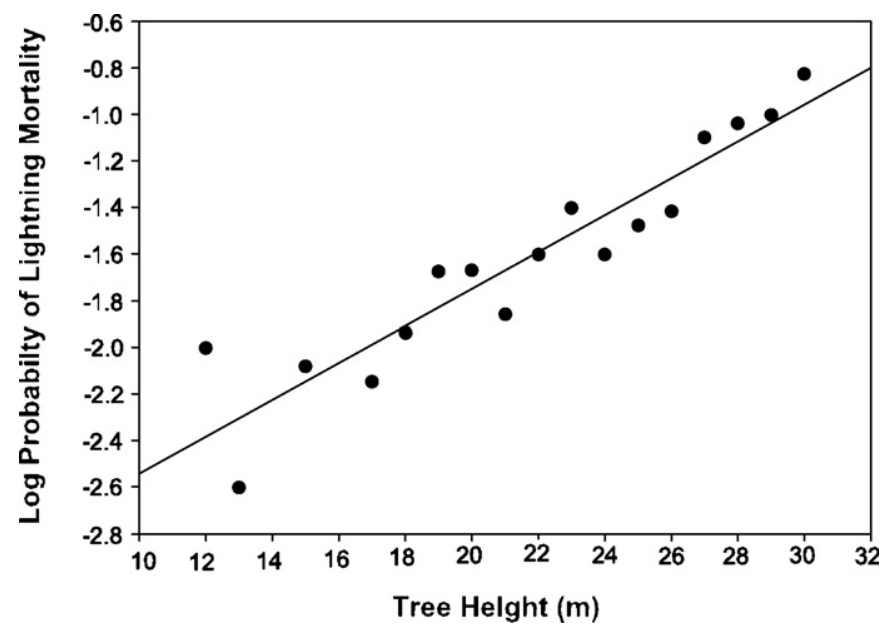

Fig. 1. Regression of lightning caused mortality on tree height for longleaf pine in stands on the Ocala National Forest in central Florida.

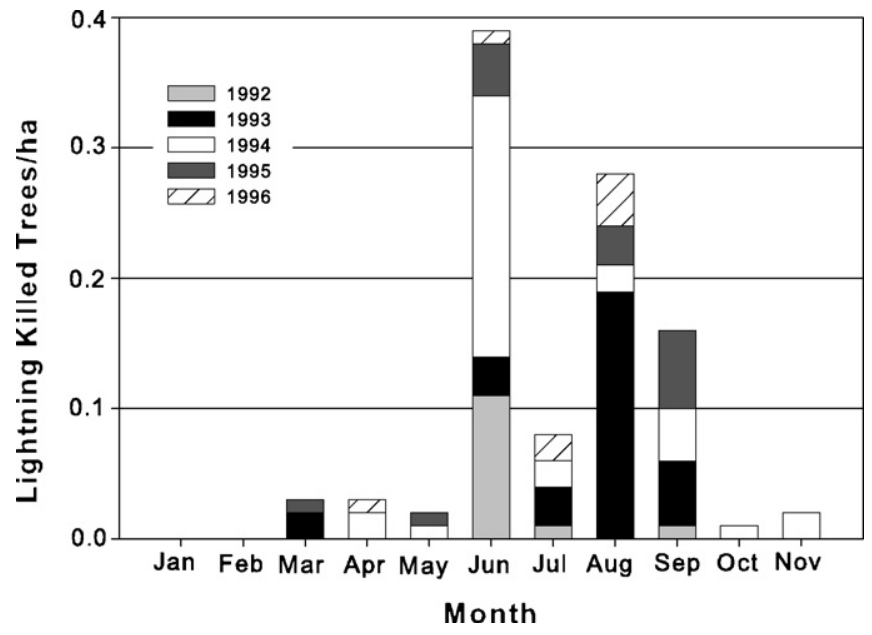

Fig. 2. Monthly mortality rates from lightning for a 5-year period in longleaf pine stands on the Ocala National Forest in central Florida.

stands on the Ocala National Forest during the hot, humid summer months of June, July, August and September when $90 \%$ of all strikes occurred. Forty percent of strikes recorded occurred in June, which also had the highest rate of 0.25 trees/ ha in 1994. Lightning strikes in longleaf study areas were second highest during August when 27\% of strikes occurred. Annual rates covered a range from just over 0.11 trees/ha in 1996 to four times greater at 0.45 trees/ha in 1999 (Fig. 3). South Carolina stands also had quite variable annual lightning occurrence with a low of 0.067 trees/ha hit in 1994 to a high of 0.16 in 1995.

\subsection{Spatial characteristics}

Longleaf pine trees in stands 1, 2 and 4 on the Ocala were not spatially different from complete spatial randomness based on the Ripley's $L(t)$ index. Trees in the sample plot in stand 3 however, were significantly clumped ( 0.01 level) at a scale of $1-25 \mathrm{~m}$. Visual inspection of the location of lightning struck

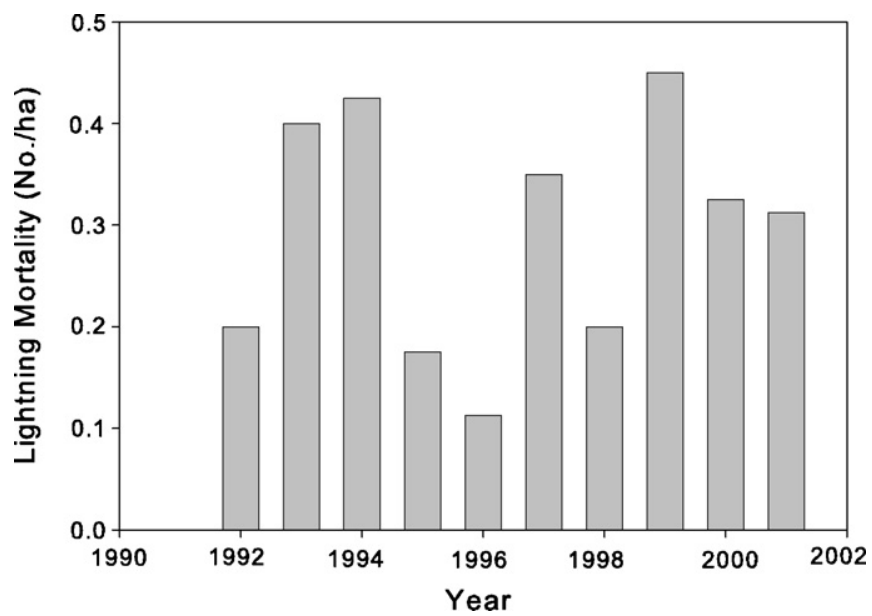

Fig. 3. Annual lightning caused mortality for a 10-year period in longleaf pine stands on the Ocala National Forest in central Florida. 

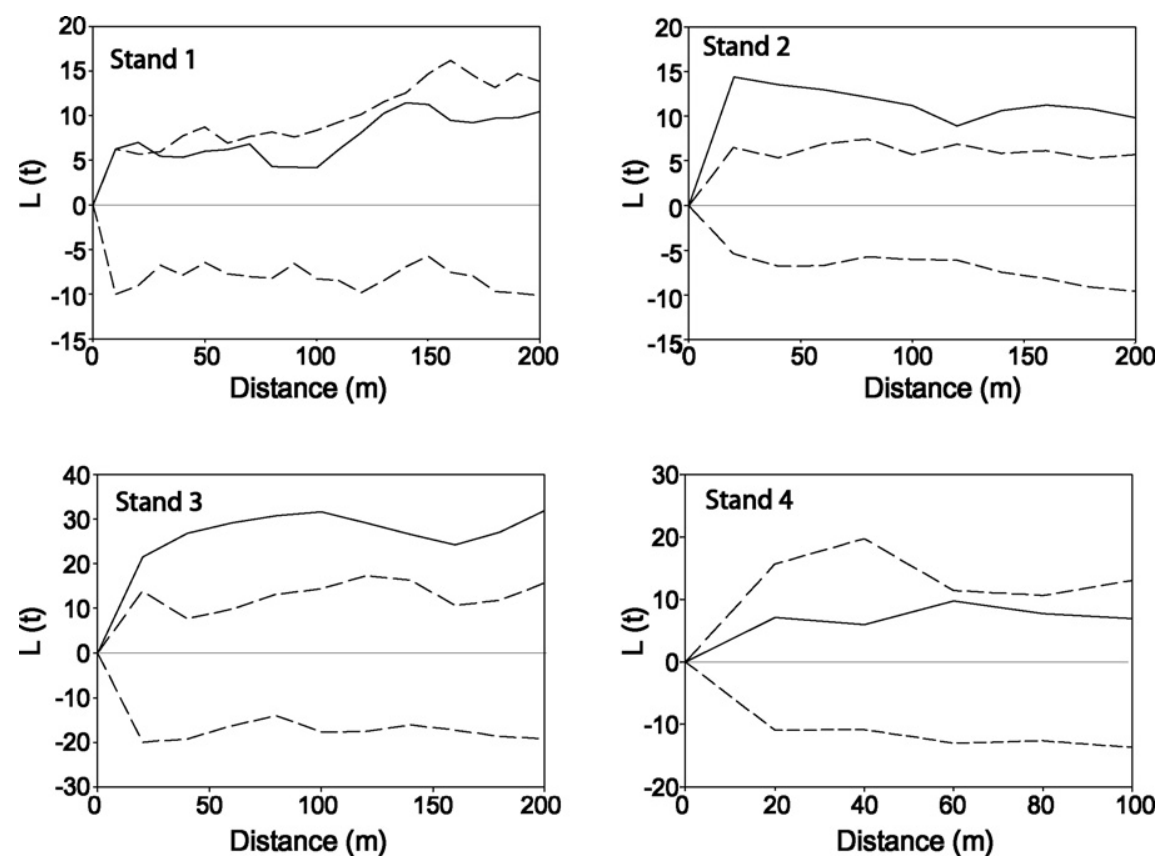

Fig. 4. $L(t)$ values for distribution of lightning struck trees over 10 years in four longleaf pine stands on the Ocala National Forest in central Florida. The solid lines are the values for trees hit by lightning and dotted lines are $99 \%$ confidence intervals based on 100 simulations for complete spatial randomness. Clumping occurs at the distance indicated when the actual values are above the confidence interval.

trees indicates some possible clumping. Spatial analyses revealed a significant clumping of lightning struck trees at the 0.01 significance level in stands 1,2 and 3 but not stand 4 (Fig. 4). In stand 1 clumping was indicated at $30 \mathrm{~m}$ with a trend toward a clumped occurrence at other distances. Stand 4 locations for lightning struck trees did not differ statistically from a completely random occurrence, although there was a trend toward clumping beyond $60 \mathrm{~m}$.

Half of all trees struck by lightning or killed by insects were on the edge of existing gaps within the Ocala stands, while only $30 \%$ of trees killed by these agents were within the forest matrix. An additional $20 \%$ of longleaf pine trees killed by lightning or insects created openings large enough for a new stand gap. Location patterns of trees succumbing to wind or fire were different with $70 \%$ located within the forest matrix, $5 \%$ in new gaps, and $25 \%$ on the edge of existing gaps.

\subsection{Lightning fires}

Data for the entire 4000 ha Riverside Island, where two of the study stands were located, was obtained from National Forest records. Over a 14-year period ending in 2003, there were six lightning fires with one each in February, May, and August and three in June. This was combined with the mean number of strikes from this study to produce ignition probabilities by month. Overall, the annual effectiveness ratio, the number of lightning strikes to ignite one fire, was 2150 strikes/fire. Based on this limited data the monthly effectiveness ratios for Riverside Island were 55, 250, 1630, and 3510 strikes/fire for February, May, June and August, respectively.

\section{Discussion}

\subsection{Longleaf mortality}

Mature longleaf pine is quite resistant to most damaging agents and thus has a low mortality rate. The overall annual rate in this study was just 0.21 and $0.05 \%$ for Florida and South Carolina stands, respectively. This is considerably lower than the $0.7 \%$ mean rate reported by Boyer (1979) for stands across the South and lower than the $0.4 \%$ for longleaf pine in southwest Georgia (Palik and Pederson, 1996). It is nearly the same however, as the 0.18 mean rate for seed trees in the panhandle region of Florida (Boyer, 1979). It does confirm that in the absence of major hurricanes, losses in mature longleaf pine stands are quite low. Mortality rates could be expected to increase as trees in these stands enter old-growth stage. Platt et al. (1988) reported a $2.4 \%$ annual mortality rate for trees larger than $70 \mathrm{~cm}$ dbh in an old-growth stand in Georgia. Oldgrowth stands with longleaf pine 175-240 years old in Louisiana averaged $1.3 \%$ annual mortality (Chapman, 1923).

The relationship between longleaf pines' historic dominance of southern forests and frequent surface fire has long been recognized (Chapman, 1932a,b; Wahlenberg, 1946) and some have even theorized that longleaf pine may have evolved traits that assist in propagation of fire on the landscape (Platt et al., 1988; Landers, 1991). This does not mean however, that longleaf pine is fire proof and cannot be killed by even mostly low intensity fires. All of the Florida stands in this study have been on a long-term prescribed burning regime over the last 20 years. These included some growing season burns, which had produced an understory dominated by grass. During the study, stands were burned three times on a 3-year return interval. 
These burns did result in the death of a few trees from ignition of basal scars or localized higher intensity fire. Mortality due to fire however, was less than from any other agent and shows, as reported by others (Boyer, 1987; Palik and Pederson, 1996), that in regularly burned stands losses to prescribed burning are extremely low.

Losses can be much higher in stands not burned in a long time and were likely higher in the historical landscape. Prescribed burning is not conducted when weather and fuel conditions become severe, but there were no such restriction for lightning ignitions. In fact, ignition probability increases as conditions become more extreme. Thus, although regularly burned areas have lower mortality (Outcalt and Wade, 2004), wildfires that historically occurred at least occasionally under more extreme conditions would have resulted in greater mortality rates of overstory longleaf pine. In addition, trees beyond 100 years old can develop butt rot that increases losses to surface fires. Chapman (1923) found losses due to fire lower than from all other causes at 0.06 trees/ha/yr, but fire did account for $9 \%$ of all mortality or double the amount found in this study.

The overall mortality from insects was relatively low. Those few trees lost in Florida were the result of a forest wide outbreak of pine sawfly that defoliated some weaker individuals. In South Carolina, bark beetles were the primary agent of insect caused mortality not associated with lightning. Insects, specifically ips bark beetles killed the majority of the trees in all stands in both locations, but these were classed as lightning induced mortality. Lightning seldom kills trees directly and immediately, which only happened to two trees in this study. However, lightning does severely damages trees, which quickly attract significant quantities of bark beetles that finish off the weakened tree.

Wind ranked second as a mortality agent, causing $13 \%$ of all overstory loss in Florida stands. In an old-growth longleaf stand in southeast Georgia, wind was also the second most important mortality agent causing $31 \%$ of all losses (Platt et al., 1988). In Louisiana old-growth stands where root rot was more prevalent, wind accounted for the most mortality at $44 \%$ (Chapman, 1923). The lower wind mortality rate in the present study was probably due to the absence of trees beyond 150 years. Most of the wind mortality, which did occur, was from one storm that produced a tornado that killed 39 trees in stand 2. Since this was a rare event referred to as the storm of the century, losses to wind are likely less on average in stands of this age range. Only six trees were blown over by winds during the rest of the 10 year study period. However, wind mortality could have been substantially higher if a hurricane had impacted the stands during the study period, which occurs about every 50 years.

It is not surprising that lightning was the major mortality agent in these longleaf stands in central Florida. Because of its location, Florida is subject to frequent thunderstorms and the lightning that accompanies them (Komarek, 1964). Previous studies by Platt et al. (1988) and Palik and Pederson (1996) in southern Georgia also found lightning was the major mortality agent. Assuming, as suggested by
Palik and Pederson (1996), that many of the trees where they were unable to determine cause of death, were killed by lightning, then lightning accounted for $72 \%$ of all mortality in their study. This is very close to the $67 \%$ found in this study in central Florida.

There was significant annual variation in lightning caused mortality and thus like many other disturbances it is episodic in nature. These high and low years were for the entire Ocala National Forest as there were no differences due to stand location. Even the low years however, were near the reported mean annual lightning density for this region of Florida, which is $10-12$ strikes $/ \mathrm{km}^{2}$ (Hodanish et al., 1997). The detection efficiency for the cloud to ground strikes during the 10 years of that study was 53-72\% or a mean of 62.5. Even, after adjusting data from Hodanish et al. (1997) to compensate for missed strikes, the lightning density in study stands was still slightly high. This means the Ocala National Forest has a higher occurrence of lightning. This could be due to local conditions like the higher elevation of this central ridge region or the location between the Oklawaha River and Lake George. These features could influence storm tracks or development and thereby increase the occurrence of thunderstorms and lightning. Alternatively, it could be as suggested by Palik and Pederson (1996) that areas with dry sandy soils have more lightning. They found a strong correlation between lightning caused tree mortality and areas with coarse textured surface soils. Vegetation types also can influence lightning strike density by influencing convective activity as shown for boreal forests in Alaska (Dissing and Verbyla, 2003). Therefore, the high lightning incidence could be due to sandhills and sand pine scrub vegetation increasing local storm development. The same pattern occurred in stands in South Carolina where the expected strike density based on the lightning detection network was lower than actual trees hit after adjusting for multiple hits and detection efficacy. At both locations, actual lightning mortality could be predicted by multiplying regional lightning density values based on the lightning detection network by a factor of 2.46 .

Seasonal lightning activity like annual is quite variable and weather driven. Previous work by Hodanish et al. (1997) for Florida separated the year into four major periods of lightning activity. November through February they labeled the cool season minimum, March through May the spring transition when lightning activity is increasing, June through August the summer maximum, and September through October the fall decline. Lightning activity in this study conducted on a much smaller area followed a similar seasonal pattern except September was part of the summer maximum while October and November were in the fall decline period. For the specific location in central Florida, based on maps in Hodanish et al. (1997), 75\% of all annual strikes occur in the summer months of June, July, and August. Data from the current study agrees with $74 \%$ of all strikes found for these months, but the absolute amount was higher at 5 strikes $/ \mathrm{km}^{2} /$ month in the current study versus 3/month shown by Hodanish et al. (1997). Thus, for monthly data there was also an under-estimation of lightning activity because the detection network missed some strikes. 


\subsection{Gap creation}

As reported by Palik and Pederson (1996) and confirmed by this study, lightning preferentially hits and removes the largest trees from stands, i.e. it thins from above. It did so in a predictable fashion following an exponential growth curve. Sometimes, however lightning would strike a short tree surrounded by taller ones. In addition, the effect of taller objects only operated over a short scale. Trees in low regions within the stands received just as many strikes as those growing on the hills, or topography did not matter on a stand scale. Minko (1975) also concluded there was no relationship between lightning strikes and topography or elevation within a pine plantation in Victoria, Australia.

Although not driven by topography, lightning strikes were clumped within stands in Florida, i.e. they tended to occur in the same areas over the 10-year period. A portion of this clumping is because some lightning strokes splinter into multiple leaders near the ground. Over $20 \%$ of all strikes were this type, which resulted in the simultaneous hit of two to four trees in a group. In addition, 50\% of all trees hit by lightning were on the edge of an existing stand gap. Thus, $70 \%$ of all strikes created or enlarged gaps within the stand. Based solely on lightning mortality rates it would take 700 years for all the trees to be killed in these stands. This is a slow turnover and therefore as suggested by Palik and Pederson (1996) it seems lighting would only create large gaps on a long time scale. However, because lightning removes the largest trees, is clumped within stands, and usually creates or enlarges gaps, the combination of attributes significantly shorten the time required to create openings large enough for longleaf pine regeneration, i.e. at least 0.1 ha, from decades to 5 or 10 years. Thus, smaller gaps are created much more quickly.

\subsection{Lighting ignited wildfire}

Although, lightning is the natural source of fire in longleaf pine forests, lightning density does not equate with fire ignitions (Podur et al., 2003). Only long continuing current lightning generates sufficient heat in vegetation to ignite fires and only about $30 \%$ of all lightning is of this type (Latham and Williams, 2001). In addition, ignition is very unlikely until fuel moisture drops below a threshold level (Nash and Johnson, 1996). Fuel moisture also interacts with precipitation amount following ignition to determine if a fire will spread or be extinguished (Rorig and Ferguson, 2002). Thus, only certain types of lightning strikes will generate enough heat for ignition and these must be accompanied by a fuel moisture level sufficiently low to allow ignition and subsequent minimal amounts of precipitation to allow for fire spread.

Even though lightning strikes are highest in longleaf stands on the Ocala National Forest in June through September, this does not mean that historically most area was burned in those months. April is the driest month although May is often nearly as dry in the central region of Florida (Hough, 1973). Although there are fewer strikes in these months, because fuels are dry and precipitation with storms often limited, ignition prob- abilities and spread are higher. The data from this study demonstrates this interaction between strikes, fuel moisture and precipitation. Although there were fewer strikes in February to May, they were more likely to ignite a fire because of drier fuel and less precipitation. The effectiveness ratio was highest in February and nearly equal to the 50/1 ratio for forests in British Columbia (Wierzchowski et al., 2002). Even though 50\% of all lightning fires were in June because there were a lot more lightning strikes, it also shows there was a long natural fire season with a portion occurring during the cool season, e.g. $17 \%$ occurred in February in this record. In addition, during the early growing season low humidity and winds that often occur should lead to larger fires from lightning ignitions. This agrees with data for area burned by lightning fires on National Forests in Florida, which was greatest during May (Robbins and Myers, 1992).

Prior to landscape fragmentation, both ignition probability and fire spread following ignition were affected by compartment size, which results from natural fire breaks. Data from Robbins and Myers (1992) for the three National Forests in Florida yields a lightning ignition rate of 1 fire/2144 ha/ 3 yrs, assuming a fire return interval of 3 years is required to maintain a longleaf habitat. Hough (1973) reported 17 lightning caused fires per year or $1 / 1750 \mathrm{ha} / 3 \mathrm{yrs}$ in sand pine scrub, which is the major vegetation type on the Ocala National Forest. Actual lightning ignitions on Riverside Island recorded by the National Forest System gives a rate of 1 fire $/ 3110 \mathrm{ha} / 3 \mathrm{yrs}$. Since all fires were put out by National Forest staff, the final size under natural conditions is not known. However, based on fuel type and continuity, days between rainfall events, and mean fire spread rates, it is likely most would have burned a large portion of the area. Even if each only burned an average of $50 \%$ of the 4000 ha Riverside area, this still yields a fire return interval of less than 5 years for the entire island.

In addition, lightning ignition effectiveness and probability of spread could have been higher in the historic landscape. Duff moisture level is a critical factor in the probability of lightning ignition in many regions (Fuquay et al., 1979; Flannigan and Wotton, 1991; Nash and Johnson, 1996) because lightning ignition often occurs when the electrical current ignites the duff at the base of the tree (Latham and Williams, 2001). A second possible scenario has been offered by Landers (1991) where the rotted snags are ignited and then smolder until the storm has passed and conditions are more conducive to fire spread. This seems possible but because snags are limited in numbers and have about the same probability as living trees of being hit by lightning, it seems like an unlikely event. Another possibility is lightning hitting a live tree and igniting decayed wood in the center surrounded by resin soaked heartwood, which then smolders for sometime following the passage of the rainstorm until burning conditions are more favorable. The grass dominated understory of longleaf pine sandhills communities dries quickly in the wind and thus would be much more likely to carry a fire from a delayed ignition of this type. Heart rot is much more prevalent in trees beyond 175 years, affecting up to $20 \%$ of old-growth stands (Chapman, 1923). Since lightning strikes the largest trees, it would have preferentially selected 
these large old trees leading to a greater probability of delayed ignition in historic stands.

Two lightning ignitions occurred in the four Florida stands over the course of this study. The first fire was in stand 1 in September 1994. This typical duff ignited fire burned a small area around the tree roughly equal to the crown diameter of 6$8 \mathrm{~m}$ and then was put out by the rainfall from the storm. Small lightning fires of this type are not detected by routine monitoring and therefore are not included in statistics. The second ignition occurred in stand 2 in February 1999. It resulted from a strike that ignited the interior of a tree with decay. The fire, fueled by the resin soaked heartwood, eventually burned through the main bole and it broke off about $4 \mathrm{~m}$ above the ground. The fallen trunk spread fire to the grassy ground cover, which burned about 1 ha before being put out by a National Forest fire control crew. Under natural conditions, this fire would have burned at least $60 \%$ of Riverside Island. A similar lightning-ignited fire was documented in a living longleaf pine in southwest Georgia by Komarek (1964). Thus, the delayed lightning fire scenario is a real possibility in longleaf pine forests.

Finally, Riverside is not a true island and fire can enter from surrounding sand pine scrub, which has an ignition rate equal to that of longleaf areas. Thus, it seems that natural ignition could be sufficient to maintain longleaf sandhills communities on the larger Islands of the Ocala National Forest like Riverside and Salt Springs, i.e. those larger than 3000 ha. Natural ignitions were surely augmented by Native American fires, and as suggested by Kalisz et al. (1986), longleaf communities prospered on smaller islands because of human set fires.

\section{Conclusion}

This study supports the general idea that having longleaf on sandhills sites will minimize risks. Longleaf trees larger than $20 \mathrm{~cm}$ diameter have very low mortality rates until they reach old age, beyond 150 years. Prescribed burning can be used to maintain ecosystem health while reducing fuel buildup and thereby wildfire risk with only an occasional tree killed by fire. Longleaf is resistant to most insects with significant losses only during southern pine beetle outbreaks. It is also very resistant to fusiform rust (Cronartium quercuum f. sp. fusiforme) (Hepting, 1971.) In the absence of hurricanes or tornadoes, wind losses are also minimal. When hurricanes do occur longleaf pine suffers less damage and possibly lower mortality (Hooper and McAdie, 1995). There is no evidence that losses to lightning are greater than for other southern pines.

Small scale disturbance patterns dominated by lightning can give us some clues in development of silvicultural systems to manage these dry site longleaf stands. Uneven-aged management of sandhills longleaf could use a combination of single tree and group selection harvest with $20 \%$ taken to create new gaps of three to four trees, $50 \%$ harvested to expand existing gaps and $30 \%$ as single trees from within the forest matrix as a starting guide. Gaps of sufficient size to promote regeneration, i.e. $0.1-0.2$ ha should be created by expanding existing gaps. A single tree selection system applied as an improvement cut, which removes trees at risk and releases the best trees for future growth, could also be used. All natural stands contain some small gaps where stems on the edge could be specifically selected for harvest. These gaps could be intentionally enlarged in future harvest cycles by removing about $50 \%$ of the trees from existing gap edges. Thus, after 2 or 3 cutting cycles, single tree selection applied in this manner could create some gaps within the stand large enough for successful longleaf regeneration, i.e. at least 0.1 ha.

Any creation or enlargement of gaps should only be applied to stands with a healthy understory dominated by grasses and forbs. Openings should not be created in stands with understories dominated by woody species, or in portions of stands dominated by woody understory. As noted by Mitchell et al. (2006), removal of the overstory in these circumstances will release this woody competition, which will further reduce any understory grasses while removing the overstory needlefall. Lack of fuel will make this patch of woody growth nearly impervious to fire and unsuitable for longleaf regeneration. Some form of chemical or mechanical treatment will be required to restore a herbaceous dominated understory to the site. This again points to the advantage of mimicking natural lightning type disturbance by enlarging existing gaps, which often are already large enough to contain advanced longleaf regeneration, rather than concentrating on making new gaps.

\section{Acknowledgements}

I thank Mike Allen, Tracy Hargraves, Marcus Williams and Robbie Williams for assistance in data collection and Pat Outcalt for data processing and statistical assistance. I am grateful to two anonymous reviewers for comments which improved this manuscript. Funding for and assistance in conducting the South Carolina portion of this study were provided by the U.S. Department of Energy through USDA Forest Service, Savannah River Natural Resource Management and Research Institute, Biodiversity Research Program, Aiken, South Carolina. I am grateful to staff of Ocala National Forest, especially Jerry Clutts, Jim Thorsen and Tommy Bailey, for providing assistance in locating and maintaining study sites.

\section{References}

Abrahamson, W.G., Hartnett, D.C., 1990. Pine flatwoods and dry prairies. In: Myers, R.L., Ewel, J.J. (Eds.), Ecosystems of Florida. University of Central Florida Press, Orlando, FL, pp. 103-149.

Baker, W.W., 1974. Longevity of lightning-struck trees and notes on wildlife use. In: Annual Tall Timbers Fire Ecology Conference Number 13, Tall Timbers Research Station, Tallahassee, FL, pp. 497-504.

Boyer, W.D., 1979. Mortality among seed trees in longleaf pine shelterwood stands. South. J. Appl. For. 3, 165-167.

Boyer, W.D., 1987. Volume growth loss: a hidden cost of periodic prescribed burning in longleaf pine? South. J. Appl. For. 11, 154-157.

Brockway, D.G., Outcalt, K.W., 1998. Gap-phase regeneration in longleaf pine wiregrass ecosystems. For. Ecol. Manage. 106, 125-139.

Brooks, R.D., Crass, D.C., 1991. A desperate poor country. Savannah River Archaeological Research Paper 2, University of South Carolina, Columbia

Chapman, H.H., 1923. The causes and rate of decadence in stands of virgin longleaf pine. Lumber Trade J. 84 (6) pp. 1, 16-17. 
Chapman, H.H., 1932a. Is the longleaf type a climax? Ecology 13, 328-334. Chapman, H.H., 1932b. Some further relations of fire to longleaf pine. J. For. 30, 602-604.

Chen, E., Gerber, J.F., 1990. Climate. In: Myers, R.L., Ewel, J.J. (Eds.), Ecosystems of Florida. University of Central Florida Press, Orlando, FL, pp. 11-34.

Christensen, N.L., 1981. Fire regimes in southeastern ecosystems. In: Mooney, H.A., Bonnicksen, T.M., Christensen, N.L., Lotan, J.E., Reiners, W.A. (Tech. Coords.), Proceedings, Conference Fire Regimes and Ecosystem Properties. Gen. Tech. Rep. WO-26, USDA Forest Service, Washington, DC, pp. 112-136.

Dissing, D., Verbyla, D.L., 2003. Spatial patterns of lightning strikes in interior Alaska and their relations to elevation and vegetation. Can. J. For. Res. 33, 770-782.

Flannigan, M.D., Wotton, B.M., 1991. Lightning-ignited forest fires in northwestern Ontario. Can. J. For. Res. 21, 277-287.

Franklin, J.F., 1992. Scientific basis for new perspectives in forests and streams. In: Naiman, R.J. (Ed.), Watershed Management: Balancing Sustainability and Environmental Change. Springer-Verlag, New York, pp. 25-72.

Fries, C., Johansson, O., Pettersson, B., Simonsson, P., 1997. Silvicultural models to maintain and restore natural stand structures in Swedish boreal forests. For. Ecol. Manage. 94, 89-103.

Fuquay, D.M., Baughman, R.G., Latham, D.J., 1979. A model for predicting lightning fire ignition in wildand fuels. Res. Pap. INT-217, USDA Forest Service, Intermountain Res. Stn., Ogden, UT.

Hardin, E.D., White, D.L., 1989. Rare vascular plant taxa associated with wiregrass (Aristida stricta) in the southeastern United States. Nat. Areas J. 9, 234-245.

Harlow, R.F., Guynn Jr., D.C., 1983. Snag densities in managed stands of the South Carolina coastal plain. South. J. Appl. For. 7 (4), 224-229.

Haase, P., 2001. Can isotropy vs. Anisotropy in the spatial association of plant species resolve physical vs. biotic facilitation? J. Vegetat. Sci. 12, 127-136.

Haase, P., 2002. SPPA-A Program for Spatial Point Pattern Analysis, Version 2.0.

Hepting, G.H., 1971. Diseases of Forest and Shade Trees of the United States. U.S. Department of Agriculture Handbook 386, Washington, DC.

Hintze, J.L., 1995. Number Cruncher Statistical System, Version 6.0. Jerry L. Hintze, Kaysville, Utah.

Hodanish, S., Sharp, D., Collins, W., Paxton, C., Orville, R.E., 1997. A 10-yr monthly lightning climatology of Florida: 1986-95. Weather Forecast. 12, 439-448.

Hooper, R.G., McAdie, C.J., 1995. Hurricanes and the long-term management of the red-cockaded woodpecker. In: Kulhavy, K.L., Hooper, R.G., Costa, R. (Eds.), Red-cockaded Woodpecker: Recovery, Ecology and Management. Stephen F. Austin State University, Nacogdoches, TX, pp. 148-166.

Hough, W.A., 1973. Fuel and weather influence wildfires in sand pine forests. Res. Pap. SE-106, U.S. Department Agriculture, Forest Service, Southeast. For. Exp. Stn., Asheville, NC.

Kalisz, P., Dorian, A.W., Stone, E.L., 1986. Prehistoric land-use and the distribution of longleaf pine on the Ocala National Forest, Florida: an interdisciplinary synthesis. Fla. Anthropol. 39, 183-193.

Komarek Sr., E.V., 1964. The natural history of lightning. In: Annual Tall Timbers Fire Ecology Conference Number 3. Tall Timbers Research Station, Tallahassee, FL, pp. 139-183.

Komarek Sr., E.V., 1968. Lightning and lightning fires as ecological forces. In: Annual Tall Timbers Fire Ecology Conference Number 7. Tall Timbers Research Station, Tallahassee, FL, pp. 169-198.

Laessle, A.M., 1958. The origin and successional relationship of sandhill vegetation and sand pine scrub. Ecol. Monogr. 28, 361-387.

Landers, J.L., 1991. Disturbance influences on pine traits in the southeastern United States. In: Annual Tall Timbers Fire Ecology Conference Number 17. Tall Timbers Research Station, Tallahassee, FL, pp. 61-98.

Latham, D., Williams, E., 2001. Lightning and forest fires. In: Johnson, E.E. Miyanishi, K. (Eds.), Forest Fires. Academic Press, San Diego, CA, pp. 375-418.

Martin, W.H., Boyce, S.G., 1993. Introduction: The Southeastern Setting. In: Martin, W.H., Boyce, S.G., Echternacht, A.C. (Eds.), Biodiversity of the
Southeastern United States, Lowland Terrestrial Communities. John Wiley \& Sons, New York, pp. 1-46.

Minko, G., 1975. Lightning strikes and their distribution in radiata pine plantations at Ovens, North-East Victoria. Aust. For. 38, 146-151.

Mitchell, R.J., Hiers, J.K., O’Brien, J.J., Jack, S.B., Engstrom, R.T., 2006. Silviculture that sustains: the nexus between silviculture, frequent prescribed fire, and conservation of biodiversity in longleaf pine forests of the southeastern United States. Can. J. For. Res. 36, 2724-2736.

Myers, R.L., 1990. Scrub and High Pine. In: Myers, R.L., Ewel, J.J. (Eds.), Ecosystems of Florida. University of Central Florida Press, Orlando, pp. 150-193.

Nash, C.H., Johnson, E.A., 1996. Synoptic climatology of lightning-caused forest fires in subalpine and boreal forests. Can. J. For. Res. 26, 1859-1874.

Outcalt, K.W., Sheffield, R.M., 1996. The longleaf pine forest: trends and current conditions. Resource Bulletin SRS-9, U.S. Department of Agriculture, Forest Service, Southern Research Station, Asheville, NC.

Outcalt, K.W., Wade, D.D., 2004. Fuels management reduces tree mortality from wildfires in southeastern United States. South. J. Appl. For. 28, 28-34.

Orville, R., 1994. Cloud-to-ground lightning flash characteristics in the contiguous United States: 1989-1991. J. Geophys. Res. 92, 10877-10886.

Palik, B.J., Mitchell, R.J., Hiers, J.K., 2002. Modeling silviculture after natural disturbance to sustain biodiversity in the longleaf pine (Pinus palustris) ecosystem: balancing complexity and implementation. For. Ecol. Manage. 155, 347-356.

Palik, B.J., Pederson, N., 1996. Overstory mortality and canopy disturbances in longleaf pine ecosystems. Can. J. For. Res. 26, 2035-2047.

Paul, J.T., Waters, M.P., 1978. Lightning fire occurrences in southeastern Georgia. Natl. Weather Dig. 3 (2), 10-15.

Peet, R.K., Allard, D.J., 1993. Longleaf pine vegetation of the southern Atlantic and eastern Gulf coast regions: a preliminary classification. In: Annual Tall Timbers Fire Ecology Conference Number 18. Tall Timbers Research Station, Tallahassee, FL, pp. 45-82.

Platt, W.J., Evans, G.W., Rathbun, S.L., 1988. The population dynamics of a long-lived conifer (Pinus palustris). Am. Nat. 131, 491-525.

Podur, J., Martell, D.L., Csillag, F., 2003. Spatial patterns of lightning-caused forest fires in Ontario, 1976-1998. Ecol. Model. 164, 1-20.

Reynolds, R.R., 1940. Lightning as a cause of timber mortality. So. For. Note 31, U.S. Department of Agriculture, Forest Service, South. For. Exp. Stn., New Orleans, LA.

Ripley, B.D., 1981. Spatial Statistics. John Wiley, New York.

Robbins, L.E., Myers, R.L., 1992. Seasonal Effects of Prescribed Burning in Florida: A Review. Miscellaneous Publication No. 8, Tall Timbers Research Station, Tallahassee, FL.

Rorig, M.L., Ferguson, S.A., 2002. The 2000 fire season: Lightning-caused fires. J. Appl. Meteorol. 41, 786-791.

Stout, I.J., Marion, W.R., 1993. Pine flatwoods and xeric pine forest of the Southern (lower) Coastal Plain. In: Martin, W.H., Boyce, S.G., Echternacht, A.C. (Eds.), Biodiversity of the Southeastern United States, Lowland Terrestrial Communities. John Wiley \& Sons, New York, pp. 373446.

Taylor, A.R., 1974. Ecological aspects of lightning in forests. In: Annual Tall Timbers Fire Ecology Conference Number 13. Tall Timbers Research Station, Tallahassee, FL, pp. 455-482.

USDA, 1941. Climate and Man: Yearbook of Agriculture. US Government Printing Office, Washington, DC, $1248 \mathrm{pp}$.

Wahlenberg, W.G., 1946. Longleaf Pine: Its Use, Ecology, Regeneration, Growth, and Management. Charles Lathrop Pack Forestry Found., Washington, DC.

Walker, J.L., 1993. Rare vascular plant taxa associated with the longleaf pine ecosystem. In: Annual Tall Timbers Fire Ecology Conference Number 18. Tall Timbers Research Station, Tallahassee, FL, pp. 105-126.

Ware, S., Frost, C., Doerr, P.D., 1993. Southern mixed hardwood forest: the former longleaf pine forest. In: Martin, W.H., Boyce, S.G., Echternacht, A.C. (Eds.), Biodiversity of the Southeastern United States: Lowland Terrestrial Communities. John Wiley and Sons, New York, pp. 447-493.

Wierzchowski, J., Heathcott, M., Flannigan, M.D., 2002. Lightning and lightning fire, Central Cordillera, Canada. Int. J. Wildland Fire 11, 41-51. 